\title{
The occurrence of the lynx in the Carpathian Mountains (south-eastern Poland) according to questionnaire data
}

\begin{abstract}
Grzegorz JAMROZY
Jamrozy G. 1990. The occurrence of the lynx in the Carpathian Mountains (south-eastern Poland) according to questionnaire data. Acta theriol. 35: 162-164.

The occurrence of the lynx Felis lynx Linnaeus, 1758 was estimated in 1986 in 342 districts of the Polish part of the Carpathian region on the basis of questionnaires distributed to the managements of hunting districts and national parks and to a group of randomly chosen hunters. The tendencies of the changes in the size of the lynx population were also evaluated for the decade 1976-1986. The lynx was permanently present in 102 of the studied areas and transiently in 72. The territory under study comprises the Carpathians proper and the eastern part of the foothills. In the eastern part of this region a decrease of the lynx population was noted in 30 districts, and an increase only in one. On the other hand, in the western part of the studied territory there was an increase in 10 districts, in 5 the lynx appeared for the first time, and only in 3 did its population diminish.
\end{abstract}

Department of Forest Protection and Wildlife Management, Agriculture Academy, 29 Listopada 46, 31-425 Kraków, Poland

Key words: distribution, Felis lynx, Poland, questionnaire data

\section{Introduction}

The lynx Felis lynx Linnaeus, 1758 appears in Poland in two widely distant regions: the forest complexes of the north-eastern part of the Polish lowland and in the mountain region of the Carpathians in the south-east (Buchalczyk 1983). There are no precise data on its occurrence and population size dynamics. It is probable that the range of occurrence of the lynx and the numbers of these animals markedly increased at first after World War II (Sumiński1973) and then decreased (Pielowski 1984). A decrease of the Carpathian lynx population was reported in the '70s from the neighbouring Slovakia (Hell 1978, Janik 1986), from where most of the lynxes reintroduced into some selected regions of western Europe originated (Čop 1986).

The aim of the present note is to describe the range of occurrence of the lynx in the Polish Carpathian Mountains and to evaluate the tendencies prevailing in the population size dynamics.

\section{Methods}

The Polish part of the Carpathian range occupying the south-eastern end of the country along the Slovakian border may be divided into the Carpathian Mountains proper characterised by abundant forests (more than $50 \%$ ) and the lower situated and mostly but poorly afforested Carpathian foothills. The whole area comprises 337 hunting districts and 5 national parks.

Material for the present paper was collected by distributing questionnaires sent in 1986 to the management of the hunting districts and of the national parks. The respondents, as in the case of the study on 
the bear (Jamrozy 1989) choose one of the following possibilities concerning the occurrence of the lynx: (1) does not occur, (2) occurs sporadically, as a migratory animal, recorded in the period 1980 - 1986 but not every year, (3) permanently present in all years. The second evaluation of the respondents concerned changes in the population size in the 1976-1986 decade and gave the possibility of the following answers: (1) the population size increased, (2) it decreased, (3) it remained without major change, (4) the lynx was noted ten years ago, but at present not and (5) it did not occur ten years ago, but now it has been recorded.

A different questionnaire was sent to a thousand randomly chosen hunters in 1986 (on the average to 5-8 from each syndicate). It concerned the species composition and the number of game shot (Jamrozy 1989). There was also a question about the occurrence of the lynx in the given hunting district.

The number of answers obtained to questionnaire I was $228(66.7 \%)$ and to II $208(20.5 \%)$. No answers were received from 38 districs. The information was supplemented by: (1) driving out into the country and obtaining local data and (2) talks with foresters and syndicate members coming to Kraków. A total of 50 interviews were organised. From 134 of the places where questionnaires were sent ( $c a$. $40 \%$ ), a information was received from several independent sources (questionnaires I and II and interviews).

\section{Results and discussion}

Of the 342 hunting districts and national parks of the Carpathian region the lynx was present in 174, in 102 of which this presence was permanent (Fig. 1). The lynx occured permanently in all the Carpathian national parks and in most of the hunting

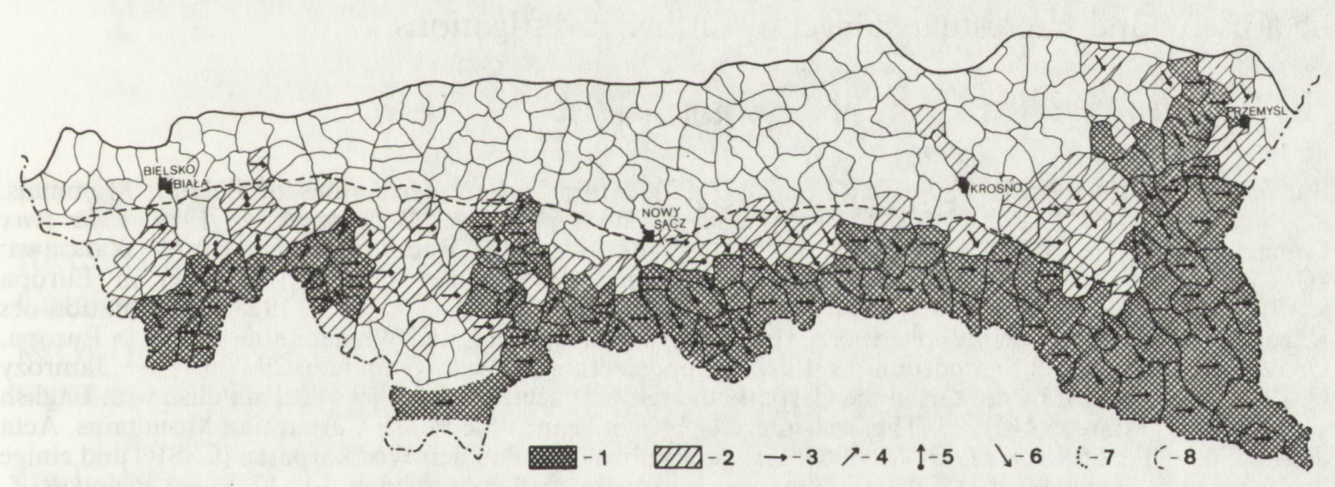

Fig. 1. The occurrence of the lynx in the Polish Carpathian region in 1986 and the tendencies in changes of its population size in the period 1976-1986. 1 - permanently present, 2 - occurs sporadically, 3 - no major changes in numbers, 4 - increase in numbers, 5 - appear where had not been noted before, 6 - decrease of numbers, 7 - line of demarcation between western and eastern parts of territory, 8 - boundary between Carpathian Mountains and foothills.

districts in the Carpathian Mountains proper, especially in their eastern part. The lynx was not noted or seen only sporadically in the practically forest-free Nowy Targ Hollow, in the Silesian Beskid, Small Beskid and part of the districts neighbouring the foothills. On the other hand, the lynx was permanently present in the eastern part of the foothills - the Przemyśl and partly the Dynów Foothils. In the Jasło-Sanok Hollows 
it could be considered as occurring sporadically. It practically did not occur in the whole of the central and western part of the Carpathian Foothills. The range of the lynx shown in Fig. 1 in the Carpathian region for 1986, although it does not much differ from that described earlier by Sumiński (1973) and Buchalczyk (1981), gives, however, more precise information of the regions of permanent and transitory presence of this species.

The number of these animals and changes in them are not known in the Polish Carpathian region. Estimates give 300-400 animals (Sumiński 1973), an exaggerated figure according to Pielowski (1984). Therefore the evaluations reported by hunters and foresters in 114 hunting districts and national parks (Fig. 1) may be interesting. In the whole territory where the lynx may occur the opinion prevailed that in the decade 1976-1986 the lynx population size did not undergo major changes $(57 \%$ of evaluations). The remaining opinions differed widely in the western and eastern part of the territory. In the western part the population increase was much more frequent (10 evaluations) and the species even spread to new areas (5 evaluations) than the decrease of numbers ( 3 evaluations), whereas in the eastern part as many as 30 evaluations reported a decrease and only one increase.

A reliable estimation of the population size of the Carpathian lynx and follow-up of the dynamics of their numbers in the particular parts of this territory will thus be a useful and interesting subject of further investigations.

\section{References}

Buchalczyk T. 1981. Lynx Felis lynx Linnaeus, 1758. [In: Keys to Vertebrates of Poland. Mammals. Z. Pucek, ed.] PWN-Polish Sci. Publ., Warszawa: 300-303. - Buchalczyk T. 1983. Felis lynx Linnaeus, 1758. [In: Atlas of Polish mammals. Z. Pucek and J. Raczyński, eds]. PWN, Warszawa: 160-161. - Cop J. 1986. Die Wiedereinbürgerung des Luchses (Lynx lynx lynx) in Europa (1970-1985). Proc. 18th IUFRO World Congress, Ljublana: 1 - 17. - Hell P. 1978. Die Situation des Karpatenluchses in der Tschechoslowakei. [In: Der Luchs. Erhaltung und Wiedereinbürgerung in Europa. U. Wotschikowsky, ed.] Symposium der Luchsgruppe. Verlag Morsak, Grafenau: 29-36. - Jamrozy G. 1988. Animals shot by hunters in the Carpathian region. Przegl. Zool. 32: 69-82. [In Polish with English summ.] - Jamrozy G. 1989. The occurrence of brown bear in the Polish Carpathian Mountains. Acta theriol. 34: 652-655. - Janik M. 1986. Grosse Raubwildarten in den Westkarpaten (CSSR) und einige Probleme ihres Schutzes. Proc. das Bärenseminar, Nationalpark Berchtesgaden: 14-17. - Pielowski Z. 1984. Stan populacji zwierząt łownych w Polsce. Sympozjum Łowieckie, Wydawnictwo AGH, Kraków: 18-47. - Sumiński P. 1973. Ryś. [The lynx]. PWRiL, Warszawa: 1-126.

Received 2 May 1989, accepted 10 October 1989. 